地 震第 2 輯

第 44 巻特集号（1991）301-314 頁

\title{
震源過程の微細構造
}

\author{
横浜市立大学文理学部物理教室* 菊 地 正 幸
}

\section{Complexity of Earthquake Source Processes}

\author{
Masayuki KıKuchi \\ Department of Physics, Yokohama City University, 22-2 Seto, Kanazawa-ku, Yokohama, 236 Japan
}

(Received November 11, 1989; Accepted October 9, 1990)

\begin{abstract}
Recent studies on source complexity such as multiple shock nature of large earthquakes are reviewed. Brief notes on the historical background as well as inversion techniques for complex body waves are also included. Through the body wave inversions, complex rupture patterns have so far been obtained for individual earthquake sources. The source complexity is characterized by the following three properties: (1) discreteness of rupture propagation; (2) heterogeneity of stress distribution; (3) hierarchy of rupture elements. These properties suggest the existence of some rate-determining processes which may be associated with 'ductile' barriers surrounding 'brittle' asperities.
\end{abstract}

Key words: Source process, Multiple shock, Complexity, Body wave inversion, Rate-determining process.

\section{§1. 発震機構から震源過程へ}

「震源過程」という言葉は比較的新しい**. 地震学会に セッション名として初登場したのは 1974 年秋であり, このころに一応の市民権を得た言葉といえよう．似たよ うな言葉として「発震機構」がある。歴史的にはこちら の方が古い. 1950 年から 60 年代にかけて精力的に行わ れた「実体波の放射パターン」の研究を背景として定着 してきた [本多 (1954)]. 発震機構は「地震源＝断層」説 が確立するまで震源研究の中心的課題であった。

「震源過程」はこの「発震機構」に引き続く研究課題を 極めて適切に表現した。すすなわち, 震源における破壊現 象を瞬間の出来事としてではなく, 有限の時間経過をむ つ「プロセス」としてとらえ，かつ，そのプロセスの背 後にある法則性を探ろうとする姿勢を含蓄している.

以下，主に浅い大・巨大地震を中心に，震源過程の研 究を総括してみる. とくに，1980 年代に盛んになった 不規則断層運動の解析に焦点をあてる. その前段とし て, 70 年代における震源過程の巨視的モデルの確立, 及 び, 微細構造研究の先駆けに簡単に触れる.

* 于236 横浜市金沢区瀬戸 22-2

** 名付け親は笠原慶一元東京大学教授と思われる。 1969 年の先生の講義ノートに, 副題として, 「震 源過程論」の文字が見える.

\section{§ 2. 震源過程の巨視的モデル}

地震の断層運動を定量化する試みの中で, HASKELL (1969) のモデルは地震の断層運動の要点をうまく表し ており，以後，標準的に用いられるようになった。 それ は変位のくいちがいが長方形の断層面に沿って一定の速 度で拡がるというあのであり，〈いちがいの時間関数と しては傾斜関数 (Ramp Function) が用いられた。 この モデルを記述する変数は約 10 個である．まず，断層面 の走向・傾斜・すべり方向 $\left(\phi_{\mathrm{S}}, \delta_{\mathrm{S}}, \lambda_{\mathrm{S}}\right)$ である.これらは 地震波の放射パターンを決める. 次いで, くいちがい量 $(D)$, ライズタイム $\left(\tau_{\mathrm{r}}\right)$, 破壊速度 $(v)$, 破壊面積 $(S=L \times$ $W)$, 破壊伝播時間 $\left(\tau_{\mathrm{p}}=L / v\right)$, 地震モーメント $M_{\mathrm{O}}$ ( $\mu D S, \mu=$ 剛性率）である. これらは波動の時間変化を決 める.

KANAMORI and ANDERson (1975) は, 1970 年代前半 までに得られたいろいろな規模の地震の震源パラメ夕を 整理し, $M_{\mathrm{S}} \geqq 6$ の地震に対し, 次のような比例関係を得 た.

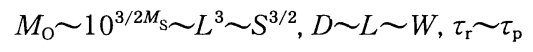
ただし， $M_{\mathrm{S}}$ は長周期表面波によるマグニチュードであ る.この経験則において特徴的なことは，くいちがい量 や破壊域の大きさが地震の規模とともに大きくなるのに 対し, 歪降下 $(D / L)$ または応力降下 $\Delta \sigma(\sim \mu D / L)$ や特 

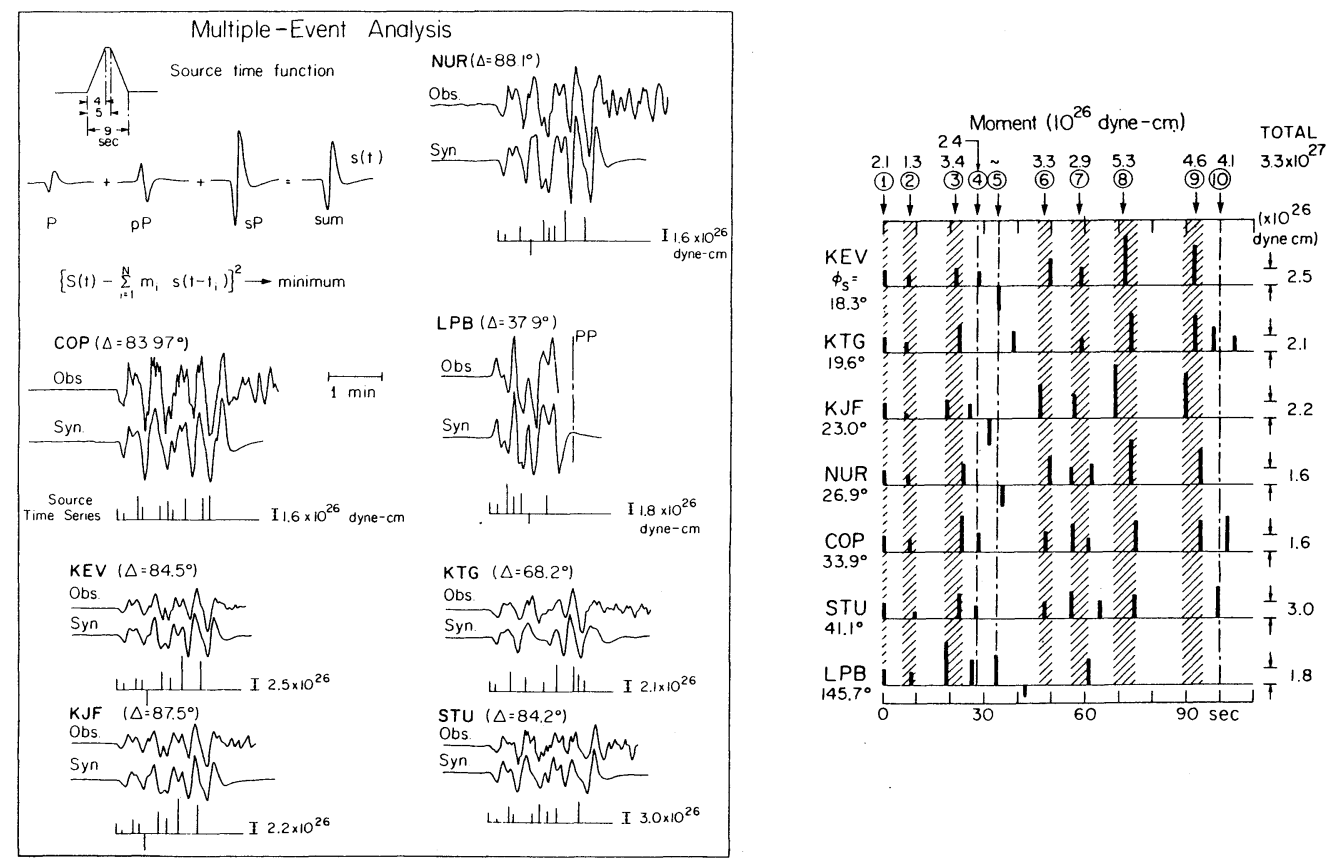

Fig. 1. Multiple event analysis of the 1976 Guatemala earthquake using far-field long-period P-waves [KANAMORI and Stewart (1978)].

性時間比 $\left(\tau_{\mathrm{r}} / \tau_{\mathrm{p}}\right)$ が地震の規模にほとんど依らないこと である.このことは，震源を一つの巨大な剪断割れ目と みなし，その割れ目の面上での摩擦すべりを考慮すれば 合理的に理解できる．このような見方を支持する事実と して，応力降下 $\Delta \sigma$ の剪断割れ目による地震エネルギー が Gutenberg-Richter のマグニチュード・エネルギー 関係式から得られる值とほどよい一致を示すことが確か められた [KANAMORI (1977)]. こうして「応力降下一定 のハスケルモデル」に要約される震源像は, 少なく之も 巨視的には，力学的に一貫性のある内容をもっているよ うに見えた。

しかし, 後で見るような震源過程の微細構造を考える とき, 上の震源像の物理的解釈は必ずしも単純ではなく なる. そもそも 1970 年代末に始まる微細構造の研究 は，震源を一つの割れ目とはみなせないことを主たる動 機として, 出発している.

\section{§3. 震源過程の微細構造の先駆的研究}

大地震で観測される実体波は，八スケルモデルから予 想される波動よりずっと複雑である。このことは，大地 震の震源がかなり不規則な破壊から成ることを物語る. このような不規則な破壊過程の 1 つのモデルが多重震 源モデルである.

大地震の多重震源性については, かなり前から指摘さ
れてきた。 たとえば, IMAMURA (1937, p. 265) は地震記 象上の特異相に注目し，1923 年の関東大地震を “multisource”地震と名付けている. また, MiYAMURA et al. (1965) は，このような多重震源の存在を構造の不均一性 に起因する大地震の本質的な側面であるとして, その研 究の重要性を説いた。

地震波形を使った多重震源の解析は, まず, 深発大地 震について着手された [OrKE (1969), FUKAO (1970)]. 深 発地震の場合, 震源近傍の地表での反射相が震源過程の 継続時間に比べてずっと後の方にやってくるので, 地震 記録から震源の情報を取り出すのが容易である.

これに対し, 浅い地震の場合には地表面での反射相が $\mathrm{P}$ 波初動のすぐ後に混在してくるので, 震源の情報を抽 出するためには，その反射相との区別が不可欠である. Helmberger らは一連の論文 [たとえば，LANGSTON and HeLMBERGER (1975)] のなかで, 浅い地震の震源過 程の解析に遠方地震（震央距離 $30^{\circ} \sim 90^{\circ}$ ) の実体波記 録が有用であること, その際, $\mathrm{P}$ 波では直達 $\mathrm{P}$ 波に加え て $\mathrm{pP}$ 相と $\mathrm{sP}$ 相を, $\mathrm{SH}$ 波では直達 $\mathrm{S}$ 波に加えて $\mathrm{sS}$ 相 を考慮すれば実用的に十分の理論記象を作れることを示 した。こうして浅い大地震についても実体波を用いた震 源過程の微細構造研究に道が開かれた。

Burdick and Mellman (1976) は, 1968 年の Borrego Mt. 地震 $\left(M_{\mathrm{S}}=6.8\right)$ の遠地実体波を詳しく調べ, 20 
Table 1. Examples of waveform inversion.

\begin{tabular}{|c|c|c|c|c|}
\hline Reference & $\begin{array}{l}\text { Source description } \\
\text { (source element*) }\end{array}$ & Green's function $^{+}$ & $\begin{array}{l}\text { Inversion } \\
\text { (constraint) }\end{array}$ & $\begin{array}{c}\text { Examples: } \\
\text { data/earthquake }\end{array}$ \\
\hline $\begin{array}{l}\text { KIKUCHI \& KANAMORI } \\
(1982,1986)\end{array}$ & $\begin{array}{l}\text { subevent sequence } \\
\text { (PD along fault- } \\
\text { strike) }\end{array}$ & ray theory & $\begin{array}{l}\text { iterative } \\
\text { deconvolution }\end{array}$ & $\begin{array}{l}\text { far-field WWSSN-LP/ } \\
\text { Guatemala(1976) } \\
\text { Tangshan(1976) }\end{array}$ \\
\hline $\begin{array}{l}\text { OLSON \& AsPEL } \\
(1982)\end{array}$ & $\begin{array}{l}\text { dislocation } \\
\text { distribution } \\
\text { (PD at grids) }\end{array}$ & $\begin{array}{l}\text { wavenumber } \\
\text { integration }\end{array}$ & $\begin{array}{l}\text { generalized in- } \\
\text { verse (confined } \\
\text { slip vector) }\end{array}$ & $\begin{array}{l}\text { near-field ground motion/ } \\
\text { Imperial Valley (1979) }\end{array}$ \\
\hline $\begin{array}{l}\text { RUFF \& KanAMORI } \\
\text { (1983) }\end{array}$ & $\begin{array}{l}\text { source time func- } \\
\text { tion (impulsive } \\
\left.\text { source: } \delta(\mathrm{t}) \delta^{3}(\mathrm{x})\right)\end{array}$ & ray theory & $\begin{array}{l}\text { generalized } \\
\text { inverse }\end{array}$ & $\begin{array}{l}\text { far-field WWSSN-LP } \\
\text { (Core diffract.)/Kurile Is. } \\
(1963)\end{array}$ \\
\hline NABELEK (1984) & $\begin{array}{l}\text { subevent sequence } \\
\text { (PD at arbitrary } \\
\text { point) }\end{array}$ & ray theory & $\begin{array}{l}\text { Gauss-Newton } \\
\text { method (weak } \\
\text { constraint) }\end{array}$ & $\begin{array}{l}\text { far-field WWSSN \& } \\
\text { GDSN body waves/Lice } \\
(1975)\end{array}$ \\
\hline TAKEO $(1987,1988)$ & $\begin{array}{l}\text { dislocation } \\
\text { distribution } \\
\text { (PD at grids) }\end{array}$ & $\begin{array}{l}\text { wavenumber } \\
\text { integration }\end{array}$ & $\begin{array}{l}\text { Gauss-Newton } \\
\text { method }\end{array}$ & $\begin{array}{l}\text { JMA strong motion/ } \\
\text { Nagano-Ken (1984) } \\
\text { Izu-Hanto (1980) }\end{array}$ \\
\hline $\begin{array}{l}\text { MoRI \& SHIMAZAKI } \\
(1984,1985)\end{array}$ & $\begin{array}{l}\text { moment } \\
\text { distribution } \\
\text { (PD at grids) }\end{array}$ & $\begin{array}{l}\text { superposition of } \\
\text { normal modes }\end{array}$ & $\begin{array}{l}\text { linear least } \\
\text { square error }\end{array}$ & $\begin{array}{l}\text { near-field short-period } \\
\text { Rayleigh/Tokachi-Oki } \\
(1968)\end{array}$ \\
\hline $\begin{array}{l}\text { KIKUCHI \& FUKAO } \\
(1985,1987)\end{array}$ & $\begin{array}{l}\text { subevent sequence } \\
\text { (PD at grids) }\end{array}$ & ray theory & $\begin{array}{l}\text { iterative decon. } \\
\text { (posive } \\
\text { moment) }\end{array}$ & $\begin{array}{l}\text { far-field WWSSN-LP/ } \\
\text { Alaska(1964), } \\
\text { Rat Is. (1965) }\end{array}$ \\
\hline $\begin{array}{l}\text { IIDA \& HAKUNO } \\
\text { (1984) }\end{array}$ & $\begin{array}{l}\text { relative disloca- } \\
\text { tion distribution } \\
\text { (PD at grids) }\end{array}$ & $\begin{array}{l}\text { records of small- } \\
\text { er earthquakes }\end{array}$ & $\begin{array}{l}\text { Forward Prob- } \\
\text { lem + mini- } \\
\text { mum error cri- } \\
\text { terion }\end{array}$ & $\begin{array}{l}\text { near-field short-period ac- } \\
\text { celerogram/Tokachi-Oki } \\
(1968)\end{array}$ \\
\hline TAKENAKA (1987) & $\begin{array}{l}\text { moment distr. } \\
\text { (PD smoothed over } \\
\text { small fault area) }\end{array}$ & DWFE & $\begin{array}{l}\text { Biggs' quasi- } \\
\text { Newton method }\end{array}$ & $\begin{array}{l}\text { JMA strong motion/Izu- } \\
\text { Hanto-Toho-Oki (1980) }\end{array}$ \\
\hline Yoshida $(1986,1988)$ & $\begin{array}{l}\text { continuous disloca- } \\
\text { tion distr. } \\
\text { (FD at small area) }\end{array}$ & ray theory & $\begin{array}{l}\text { Gauss-Newton } \\
\text { method (weak } \\
\text { constraint) }\end{array}$ & $\begin{array}{l}\text { GDSN LP \& IP/Izu-Bonin } \\
(1983) \text { South Honshu } \\
(1984)\end{array}$ \\
\hline $\begin{array}{l}\text { FUKUYAMA \& IRIKURA } \\
(1986)\end{array}$ & $\begin{array}{l}\text { relative moment } \\
\text { distribution } \\
\text { (PD at grids) }\end{array}$ & $\begin{array}{l}\text { records of after- } \\
\text { shocks }\end{array}$ & $\begin{array}{l}\text { Gauss-Newton } \\
\text { method }\end{array}$ & $\begin{array}{l}\text { JMA strong motion (S \& } \\
\text { D type)/Nihonkai-Chubu } \\
(1983)\end{array}$ \\
\hline Коуама (1987) & $\begin{array}{l}\text { time function of } \\
\text { moment tensor } \\
\text { (moment tensor el- } \\
\text { ement) }\end{array}$ & ray theory & $\begin{array}{l}\text { singular value } \\
\text { deconposition }\end{array}$ & $\begin{array}{l}\text { far-field WWSSN-LP body } \\
\text { wave/Nihonkai-Chubu } \\
\text { (1983) }\end{array}$ \\
\hline
\end{tabular}

* $\mathrm{PD}=$ point dislocation; $\mathrm{FD}=$ finite-length dislocation.

$+\mathrm{DWFE}=$ discrete wavenumber/finite element.

秒間余の観测波形が主破壊と 2 つ小破壊によってう まく説明できることを示した. KANAMORI and STEWART (1978) は, 1976 年 Guatemala 地震 $\left(M_{\mathrm{S}}=7.5\right)$ を調 へ，観測された実体波が約 10 個の小破壊の重ね合わせ によってうまく合成できることを示した (Fig. 1). この 段階では小破壊の抽出はまだかなり試行錯誤的であった が,やがてこれらの研究を契機に, 複雑な地震記録につ いてのインバージョン法が次々に開発された.

\section{§4. 微細構造を抽出するための地震波インバージョ} ン法

Table 1 に, 1980 年代に開発されたいろいろな地震 波インバージョン法を示す. いずれの方法にも共通する 考え方として, まず震源をある種の単純な要素の重ね合 わせとみなすこと, その上で, 観測波形に理論波形が何 らかの意味で最も良く合うように各要素のパラメターを 決める，ということである。あう少し具体的に言えば, いずれの方法も次のような 3 つの手順を含んでいる.す なわち, (1) 震源の表現（震源要素の定義）(2)グリーン 
関数の評価 (震源要素に対する理論記象の計算) (3) 最適 化（最小二乗法の数值的技法）である.

(1) 震源の表し方

震源過程の時間変化を表す方法として, 地震モーメン トの時間変化率（モーメント速度関数） $\dot{M}_{\mathrm{O}}(t)$ がよく使 われる. これは近似的に無限弾性体中の遠方での变位波 形に相似な関数である.すべり面上 $\boldsymbol{x}$ でのくいちがい速 度を $\dot{D}(t, \boldsymbol{x})$ とすると

$$
\dot{M}_{\mathrm{o}}(t)=\mu \iint \dot{D}(t, \boldsymbol{x}) d S
$$

と与えられる.くいちがい関数が場所によらないとき， (1) 式はくいちがい速度 $\dot{D}(t)$ と断層面積拡大速度 $\dot{S}(t)$ の コンボリューションで置き換えられる：

$$
\dot{M}_{\mathrm{O}}(t)=\mu \int \dot{D}(t-\tau) \dot{S}(\tau) d \tau
$$

$\dot{M}_{\mathrm{O}}(t)$ のフーリエ変換の絶対値は「震源スペクトル」と 呼ばれ，震源の特徴的なサイズや統計的性質を調べると きに用いられる。

震源要素の与え方として, 代表的に次のような $(\mathrm{A})$, (B) 2 通りの方法がある。これらはある程度の互換性を あつが, 完全に等価ではない。

(A)くいちがいの場による表現

断層面をいくつかの小領域（ふつう矩形要素）に分割 し，それぞれの小領域におけるくいちがい関数によって 震源過程を表す．記録の分解能やインバージョンの安定 性などを考慮して, くいちがいは一ヶ所一度だけ起こる ものと仮定されることが多い. この場合, 各小領域 $(i$ 番 目）のくいちがい運動を特徵づける量は，くいちがい関

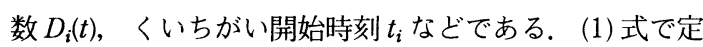
義されるモーメント速度関数 $\dot{M}_{\mathrm{O}}(t)$ は，各小領域からの 寄与をたしあわせて

$$
\begin{aligned}
& \dot{M}_{\mathrm{O}}(t)=\sum_{i} m_{i}\left(t-t_{i}\right) \\
& m_{i}(t)=\mu \int \dot{D_{i}}(t-\tau) \dot{S_{i}}(\tau) d \tau
\end{aligned}
$$

のように与えられる.

(B) サブイベントの時空分布による表現

時間的空間的に見てひと塊りの断層運動を一つのサブ イベントとみなし，そのサブイベントの系列によって震 源過程を表す. 各サブイベントはメカニズム解, 大きさ (地震モーメント), 発震時刻, 位置, 継続時間, 破壊領 域などによって特徴づけられる。 サブイベントの数が多 い場合には，未知数を減らすためにメカニズム解などは 一定とみなされることが多い，その場合，モーメント速 度関数 $M_{\mathrm{O}}(t)$ は (2) 式と同じ形で表される. ただし添字 $i$ はサブイベントの順番を表すすのとする.

(2) グリーン関数の評価

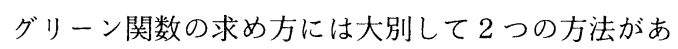
る. 1 つは理論的に計算する方法, あう 1 つは, 震源域 内で起こった小地震（余震）の記録を利用する方法であ る. 前者についてはさらに, 観測データの種類（近地地 震か遠地地震か，実体波か表面波かなど）に応じていく つかに分けられる．実体波を例にあげれば，次のような 方法がある.

(A) 波線理論による方法

震央距離 $\Delta$ が $30^{\circ}<\Delta<90^{\circ}$ の遠地実体波に対して適 用される。この範囲では, 波線経路による波形の変化が 小さく, $Q^{-1}$ の影響を考慮するだけで十分な近似が得ら れる.

(B) 波数積分法

近似地震の強震記録などに適用される，水平成層構造 について, 变位を水平座標の固有関数で展開し, 鉛直座 標に依存する係数を弾性波動論的な扱いで求める.

(C) 小地震の観測記録加らの変換法 (半経験的手法) 理論計算の代わりに，小地震の観測記録を代用する方 法である.ふつつう, 小地震の記録をそのままグリーン関 数とするのではなく, 本震との大きさの違いによる震源 パラメ夕の違いを考慮し，特性時間（ライズタイム）な どの補正をしてから用いる。

(3) 最適化

震源を記述するパラメタを $\boldsymbol{x}=\left\{x_{j} ; j=1, \ldots, m\right\}$ ，観測 データを $\boldsymbol{y}=\left\{y_{i}: i=1, \ldots, n\right\}$ とおく．また， $y_{i}$ に対する 理論値（式）を $f_{i}(\boldsymbol{x})$ と表す。インバージョンとは何らか の意味で理論值 $\left\{f_{i}(\boldsymbol{x})\right\}$ が観測デー夕 $\left\{y_{i}\right\}$ に最む良く合 うように，モデルパラメタを決めることである.

大別して, 2 つ最適化問題がある. 1 つは, モデルパ ラメ夕について何らの先験的情報がない場合の最適化で ある. この場合, 理論值と観測値の差の二乗和を最小に することが最適条件とみなされる，すなわち，

$S(\boldsymbol{x})=\sum_{i}\left\{y_{i}-f_{i}(\boldsymbol{x})\right\}^{2}=$ 最小

である.

あう 1 つは，モデルパラメ夕に関しての先験的情報ま たは束縛条件がある場合の最適化問題である. たとえ ば，先験的情報として

$x_{j}$ : 平均値 $x_{j}^{m}$ のまわりに分散 $\sigma_{x j}{ }^{2}$ の正規分布 が与えられているとする．この場合，観測デー夕 $y_{i}$ の誤 差の分散を $\sigma_{e i}{ }^{2}$ とすると, 最尤推定に基づく最適化条件 は

$$
\begin{aligned}
S(\boldsymbol{x}) & =\sum_{i}\left\{y_{i}-f_{i}(\boldsymbol{x})\right\}^{2} / \sigma_{e i}{ }^{2}+\sum_{j}\left(x_{j}{ }^{m}-x_{j}\right)^{2} / \sigma_{x j}{ }^{2} \\
& =\text { 最小 }
\end{aligned}
$$

で与えられる.

モデルパラメ夕に対する先験的情報または束縛条件 は, 解の安定性・信頼性に対して極妨て重要な役割を果 
たすことが多い，代表的な束縛条件として，すべりの向 きの一貫性やくいちがい量の空間分布のなめらかさなど がよく用いられる [HARTZELL (1989)].

この他, 多数のサブイベントの時空分布を求める方法 として反復はぎとり法がある，そこでは，まず 1 つのサ ブイベントのモデルパラメタを $\boldsymbol{x}^{(1)}$ として, $\boldsymbol{f}\left(\boldsymbol{x}^{(1)}\right)$ が観 測データ $\boldsymbol{y}$ に最も良く合うように， $\boldsymbol{x}^{(1)}$ を決める。すな わち

$$
\left\|\boldsymbol{y}-\boldsymbol{f}\left(\boldsymbol{x}^{(1)}\right)\right\|=\text { 最小 }(\|\cdots\|=\text { ノルム })
$$

次に，観測データから $\boldsymbol{f}\left(\boldsymbol{x}^{(1)}\right)$ をはぎとり，残差記録を $\boldsymbol{y}$ と置き変える：

$$
\boldsymbol{y} \leftarrow \boldsymbol{y}-\boldsymbol{f}\left(\boldsymbol{x}^{(1)}\right)
$$

そして，この $\boldsymbol{y} に \boldsymbol{f}\left(\boldsymbol{x}^{(2)}\right)$ が最も良く合うように，2 個目 のサブイベントのモデルパラメタ $\boldsymbol{x}^{(2)}$ を決める. 同様に して，(6) と (7) の手順の繰返しで， $\boldsymbol{x}=\boldsymbol{x}^{(1)}+\boldsymbol{x}^{(2)}+\cdots$ と 解を求めていくのが反復はぎとり法である.

\section{§5. 実体波インバージョンで得られたこと}

今日，複雑な地震記録のインバージョン法については 一通り出尽くした感があり, 焦点は個々の地震の解析結 果の蓄積に移りつつある. しかし，得られた結果の何に 注目すべきか，どこまで有意性があるか，あるいは，力 学的な意味づけなどについては，まだ混沌の状況にある と言ってよいであろう.

以下，まず，震源過程の微細構造に関する概念的モデ ルについて述べ, 次いで, 地震波のインバージョンに よって得られた結果をやや羅列的に示す.

\section{不均一断層運動に対する概念モデル}

震源過程の不規則性は, より根元的には，断層面上の 不均一強度分布を反映したものと考えられる.この不均 一性は, 短周期地震動の励起 [MiKumo and MiYATAKE (1987)]をはじめ, マグニチュード・頻度分布, 前震・本 震・余震の発生パターン [茂木 $(1967)]$, さらには破壊 現象一般 [平田 (1987)] としての地震の諸特性を規定し ている根元といえる.

断層面上の強度の不均一性を概念化したモデルとし て，金森らのアスペリティモデル [LAY et al. (1982)] と 安芸らのバリアモデル [DAS and AKI (1977), AKI (1979)]，また，類似のモデルとして断層パッチモデル [小山 (1983)] がある (Fig. 2).

バリアむアスペリティも強度の大きい部分を表現した あのであるが, 両モデルは本震の震源過程について対照 的な内容を持つ. まず, バリアモデルでは, 強い部分の 割れ残しが震源過程の不規則性の主要因であり, また, その割れ残し部分への応力集中が余震発生の主要因と見 る.これに対し，アスペリティモデルでは，強い部分の
破壊こそ本震の主要過程であり，それを取り囲む弱い部 分は前震の発生パターンを形成すると見る.

それぞれのモデルについて，震源パラメタ間の相関 （地震モーメントと応力降下など）に違いのあることが 指摘されている [MADARIAGA (1979), RUDNICKI and KANAMORI (1981)]. しかし，それらを実際に波形解析の 上で区別することの難しさも指摘されている [DAs and Kostrov (1988)]. 現実的には, 断層面の強い部分はバ リアにもアスペリティにあなり得るであろうから，いず れか一方が真で他が偽というあのではないであろう。 ま た，後述するように，アスペリティとバリアは，それぞ れ異なる時定数に対する「強度」として, 統一的に理解 され得る.

このほか, 震源過程の不規則性に関連ある概念モデル として，階層モデル [FuKAO and FURUMoTo (1985)] が あげられる (Fig. 2d). このモデルはもともとは本震と余 震の間のマグニチュードギャップなどいくつかの地震学 的な状況証拠に基づいて作られたものであるが，関連あ りそうな事柄として次の地質学的な事実は興味深い. す なわち, 松田 (1988) によると, 個々の大地震に相当する 「断層帯」（長さ $10 \sim 100 \mathrm{~km}$ ) はその下部構造として 「断層線」(長さ数 $\mathrm{km}$ ) を持ち, さらにその下部構造とし て「地割れ」(長さ数 $\mathrm{m}$ ) を持つ。このような階層構造は 地震源の特徵的なサイズ分布や波動のスペクトルを規定 する要因となろう.

アスペリティの分布パターン

Ruff やLay らは, 大地震の実体波インバージョンで 得られた震源時間関数から, アスペリティの大きさと分 布を推測した [たとえば LAY and KANAMORI (1980), RUFF and KANAMORI (1983)]. そして, 北太平洋の沈み 込み帯に沿ったいろいな大地震を比較する中で, アスペ リティと沈み込み帯のテクトニクスとの関連性を調べ, Fig. 2c のように，いくつかにパターン化した[LAY et al. (1982) ]. すなわち,「さしわたし $500 \mathrm{~km}$ べた一面 アスペリティ」のチリ型から, アリューシャン型, 千島 型を経て，「べた一面非アスペリティ」のマリアナ型であ る.これにより地震の発生パターンが沈み込み帯の年代 や沈み込み速度に密接に関係していることが示された。

また, KANAMORI and McNALLY (1982) はコロンビア 西海岸の同じ地域で起こったいくつかの大地震を調べ, 複数のアスペリティの破壊が個々のアスペリティの破壊 よりもずっと大きな地震モーメントの解放をもたらすこ とを指摘した. RUNDLE and KANAMORI (1987) はこのよ うな複数アスペリティの相乗効果に注目し, 逆に, 個々 のアスペリティの特性を求めた.

短周期源と長周期源 


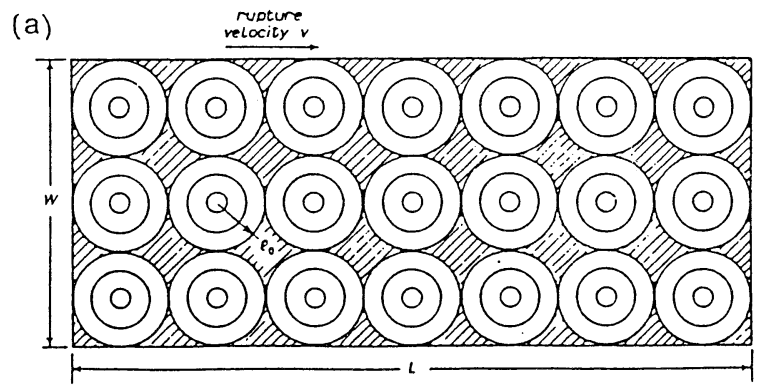

(b)

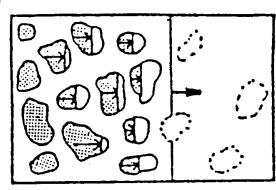

a

(c)

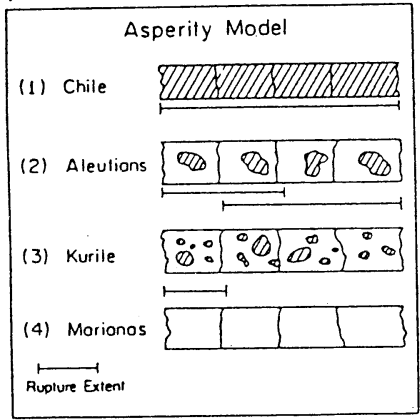

(d)
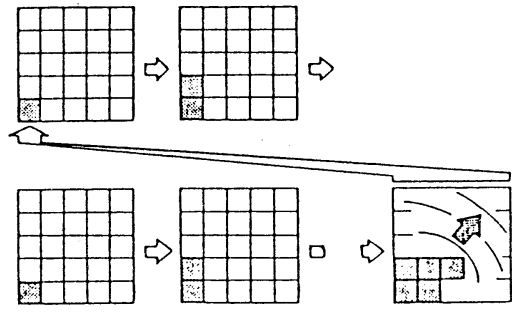

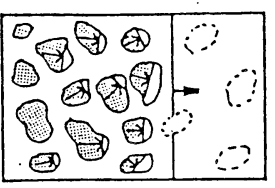

b

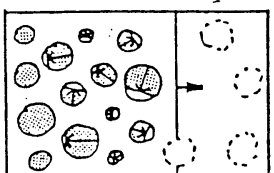

C
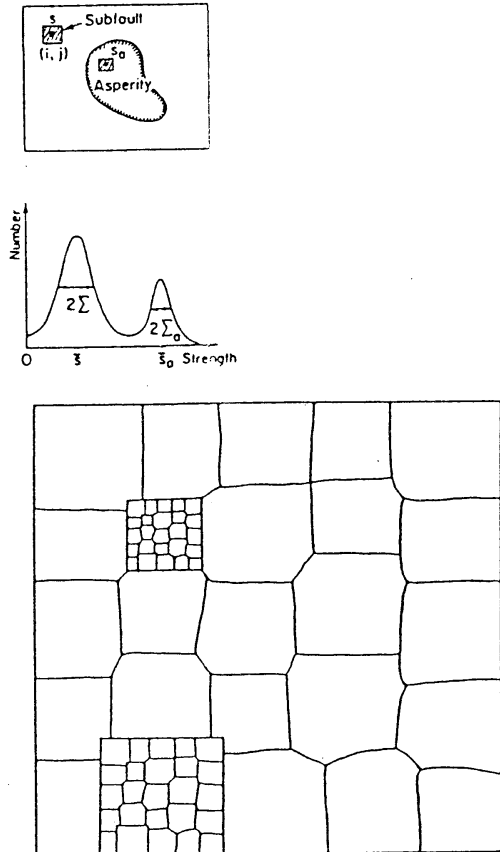

Fig. 2. Models proposed to explain complexities of radiated seismic waves.

(a), Barrier model from PAPAGEORGIOU and AKI (1983); (b), Fault patch model from Koy AMA (1983); (c),

Asperity model from LAy et al. (1982); (d), Hierarchy model from Fukao and Furumoto (1985).

1968 年の十勝沖地震 $\left(M_{\mathrm{S}}=7.9\right)$ については, 加速度 強震記録から津波に至るまでいろいろな記録を用いた解 析がなされている. KIKUCHI and FUKaO (1985) は遠地 長周期実体波による多重震源解を求め, 初期破壊ステ一 ジの存在や最大サブイベントが断層の端付近で起こった ことなどを示した (Fig. 3a). MORI and SHIMAZAKI (1984，1985) は，加速度強震記録やWWSSN の短周期 実体波などを用いて 2 個の短周期発生源を同定し，それ が周期 10〜25 秒の近地表面波のインバージョンによる
くいちがいの空間分布と調和的であることを確かめた (Fig. 3b). IIDA and HAKUNo (1984) は加速度強震記録を 用いて, 短周期地震動の発生源の時空分布を求め, それ が長周期実体波の解析結果と概ね一致することを示した (Fig. 3c).さらに, SATAKE (1989) は津波の波形記録の インバージョンを行い, 地震波解析の結果とだいたい一 致する結果を得た (Fig. 3d)。これらの結果を総合する と, 短周期・長周期地震動の発生源は時間的にも空間的 にも密接に関連し合っていると言えよう。 


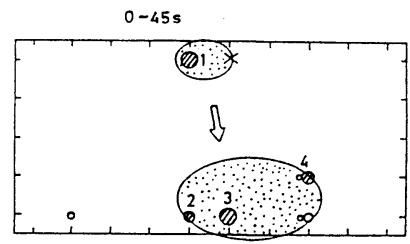

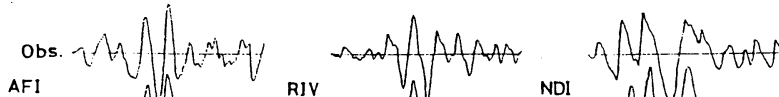

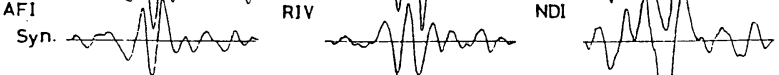

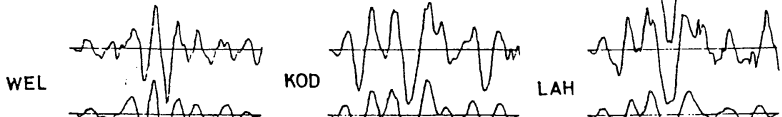
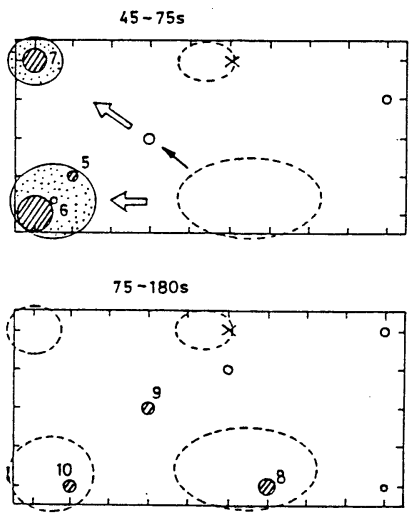

Spatial distribution of point sources for three time intervals: (a) $0 \leq 1 \leq 45$ s: (b) $45 \leq 1 \leq 75$ s: (c) $75 \leq 1 \leq 180$

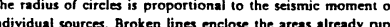
tured.

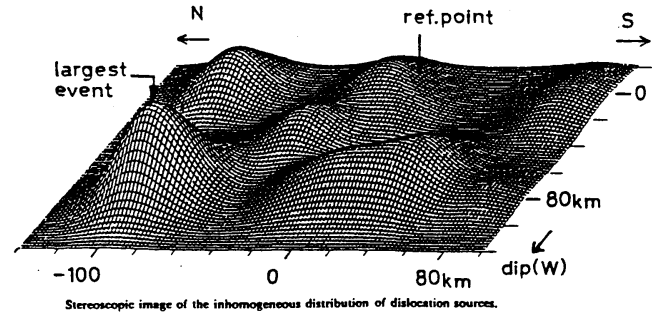

Fig. 3(a)
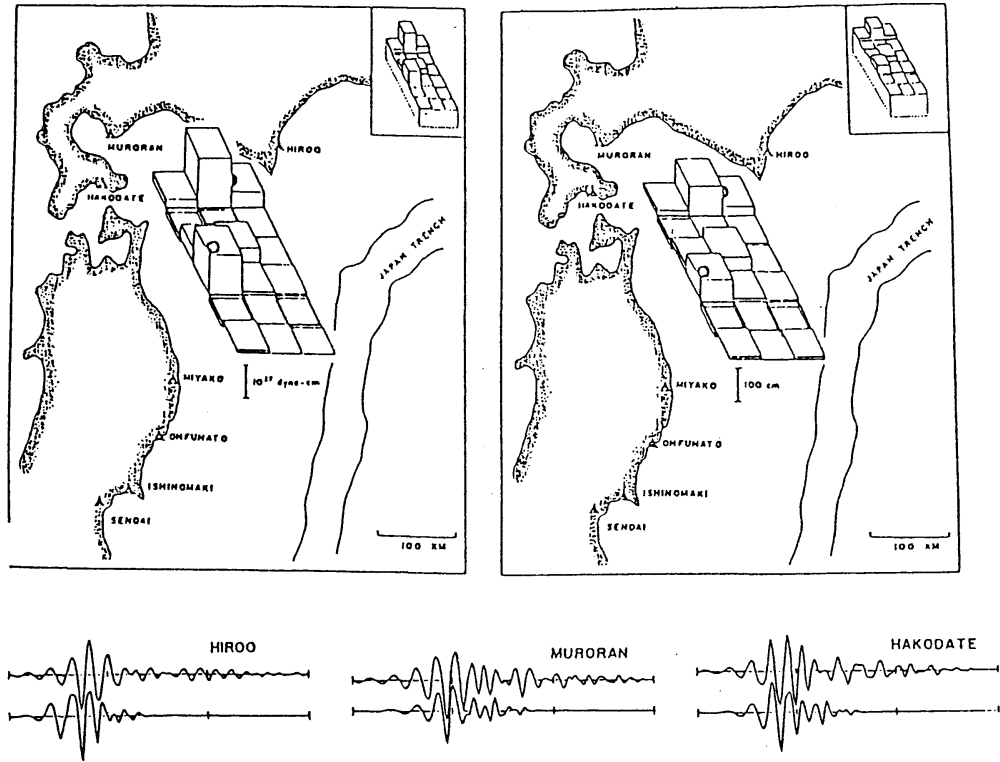

PIYAKO
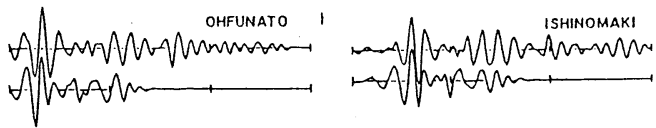

BILATERAL

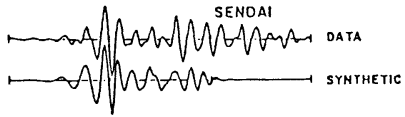

Fig. 3(b) 

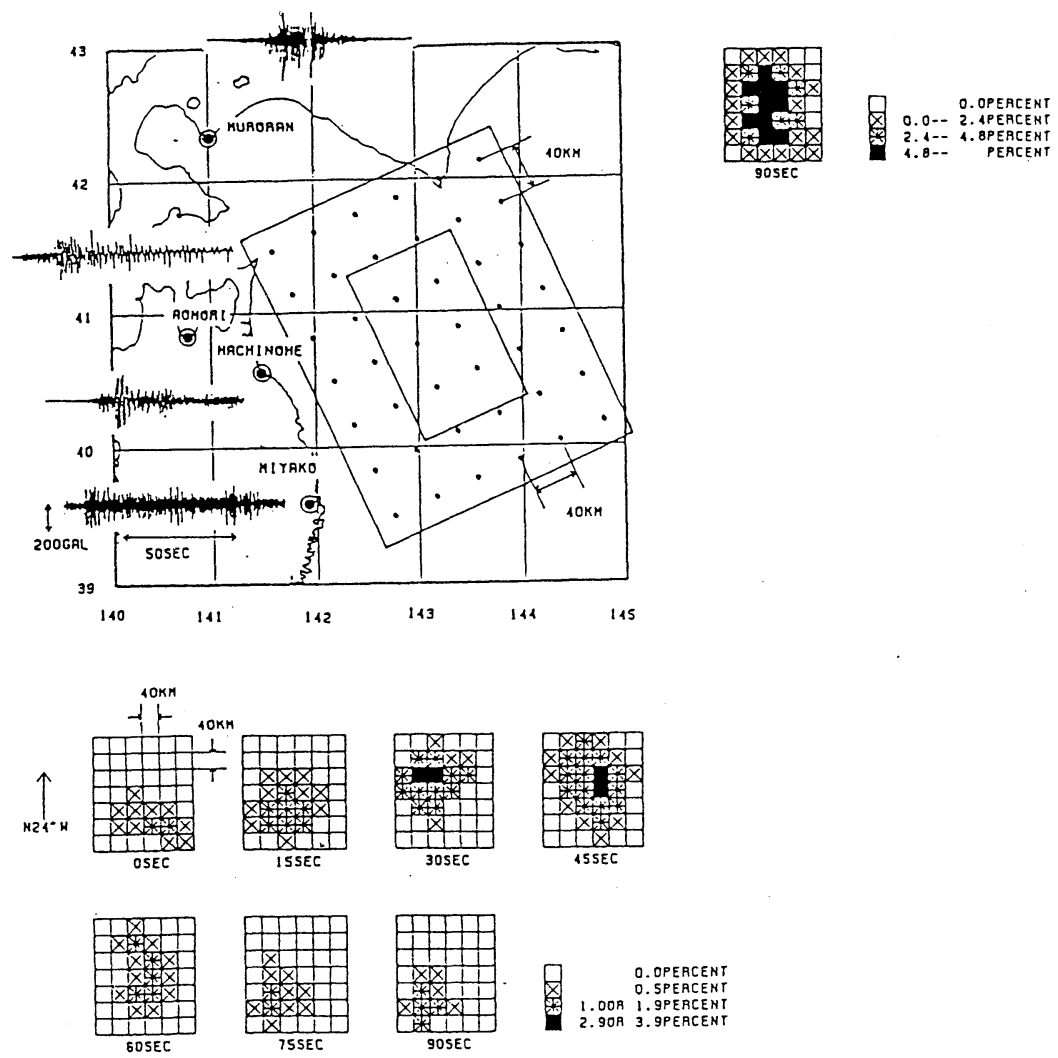

Fig. 3(c)

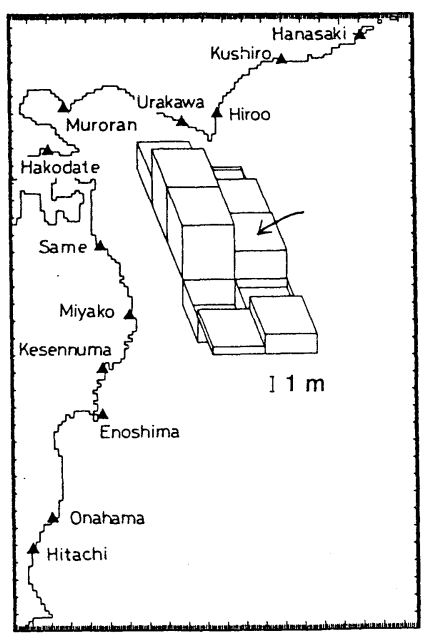

1968 Tokachi-oki
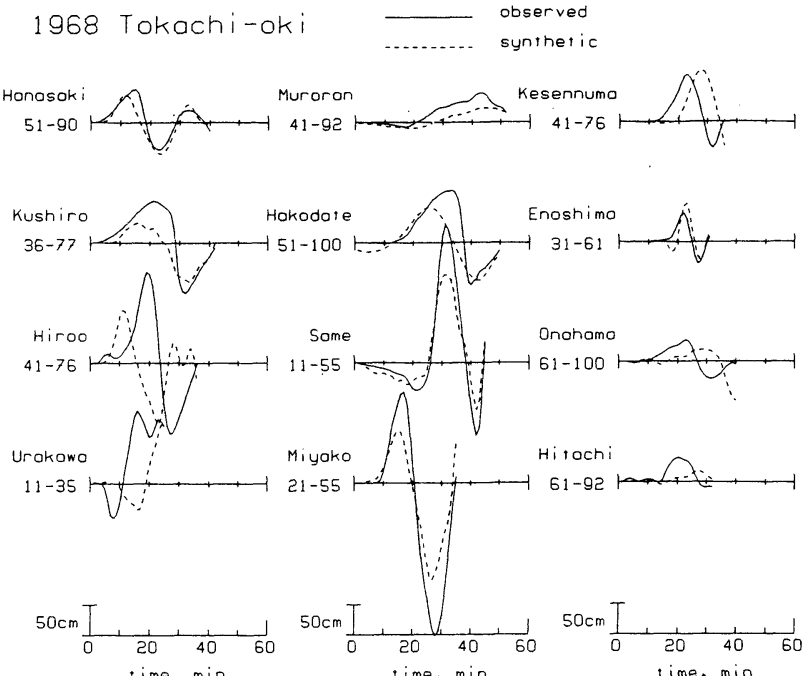

Fig. 3(d)

Fig. 3. Source process of the 1968 Tokachi-Oki earthquake obtained from various kinds of observed records.

(a), Far-field long-period P-waves [KIкuchi and Fukao (1985)]; (b); Short-period P-waves and intermediate-period Rayleigh waves [MoRi and SHIMAZaKI (1984, 1985)]; (c), Short-period accelerograms [IIDA and Hakuno (1984)]; (d), Tsunami waveforms [Satake (1989)]. 

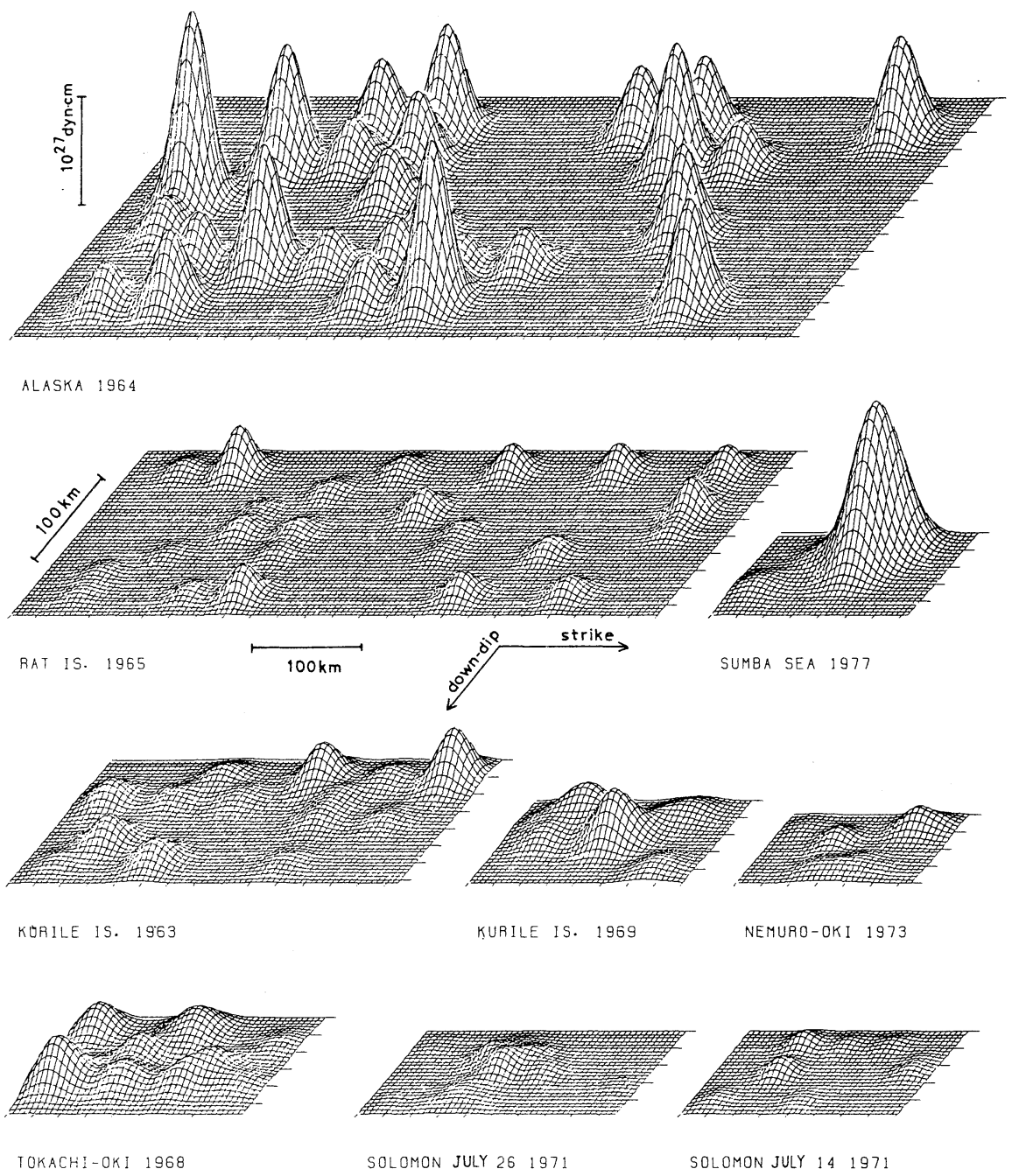

Fig. 4. Heterogeneous dislocation sources in great earthquakes along subduction zone [KIKUCHI and FuKAo (1987)].

\section{応力降下の 2 面性とくいちがい分布の階層構造}

KIKUCHI and FUKAO (1987) は, 沈み込み帯の大地震 （モーメントが $7 \times 10^{27} \sim 8 \times 10^{29} \mathrm{dyn} \cdot \mathrm{cm}$ ） 9 個につい て多重震源の時空分布を求めた (Fig. 4). その結果, これ らの地震にほぼ共通に，時定数 10 秒程度の小破壊が含 まれること，平均的破壊速度は $1 \sim 3 \mathrm{~km} / \mathrm{s}$ で $\mathrm{S}$ 波速度 より有意に遅いこと, 局所的応力は破壊域の端付近で最 大となることが多く，その值は平均応力よりほぼ 1 桁大 きいことなどを見い出した，また，モーメントマグニ チュード $M_{\mathrm{W}}$ が 9 クラスの巨大地震では, このような小 破壊の寄せ集めだけでは全体の地震モーメントを説明し 切れず，したがってより長い時定数を持った破壊要素が 含まれるべきことを示し，〈いちがい分布の階層的構造 を示唆した。

\section{不均一断層運動と地質構造の関連}

1979 年の Imperial Valley $\left(M_{\mathrm{L}}=6.6\right)$ 地震では, 断層 の走向に垂直に張られた強震計アレイの記録が最大限活 用され,すべり運動についての詳細な微細構造が得られ た。まず，HARTZELl and HELmBERgER (1982) は破壊速 度一定の拘束条件付きでくいちがい量の分布を求めた が，その後，ARCHULETA (1984) は破壊フロントのみな らず，〈いちがい速度やライズタイムをも未知变数とし て，その空間分布を求めた.

TAKEO $(1987,1988)$ は日本の内陸型地震について強 震記録のインバージョンを行い，断層面上のくいちがい 分布を求めた。 そして，〈いちがいの大きい部分で顕著 な余震が少ないことや単成火山群が地款の弱部となって いることなどを明らかにした (Fig. 5). 本震のすべりと 


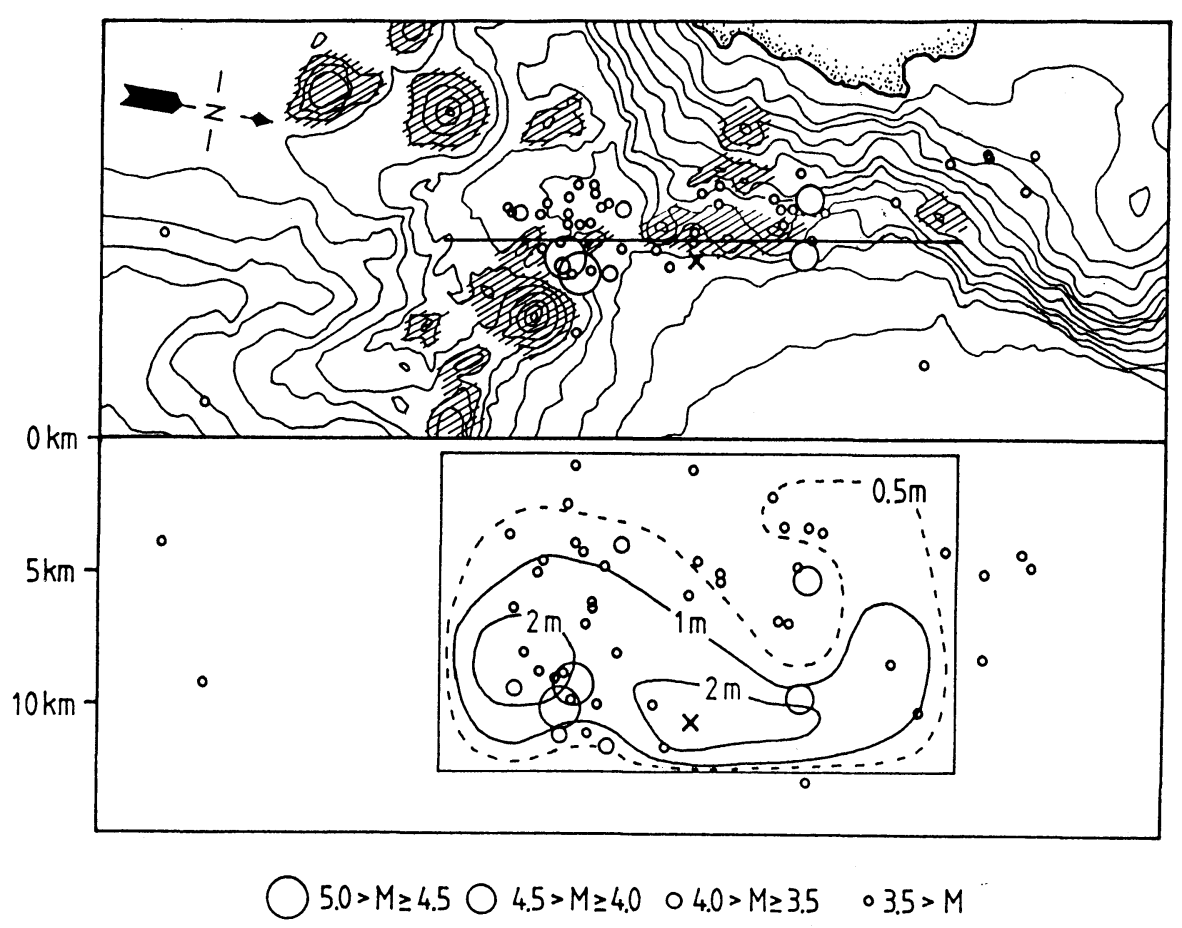

Fig. 5. Comparison of dislocation sources obtained in waveform inversion with aftershock distribution and submarine volcanoes (shaded) [TAKEo (1988)].

前震・余震活動との相補性については, 1980 年伊豆半 島東方沖地震 $(M=6.7)$ についての TAKENAKA (1987) の研究にも見られる.

SATo (1985) は, 1983 年日本海中部地震 $\left(M_{\mathrm{S}}=7.7\right)$ の強震加速度記録を解析し, 初期破壊点付近及び北北東 $40 \mathrm{~km}$ 余の地点に強い短周期発生源を同定した。また, それら短周期発生源の間に低い余震活動帯があることに 注目し, 延性的なバリアの存在を示唆した.

\section{メカニズムの変化}

震源過程の不規則性の要因として，とくに内陸の大地 震などでは, 複数断層にわたるすべり破壊む無視できな い. NABELEK (1985) は, 1980 年アルジェリア地震 $\left(M_{\mathrm{S}}\right.$ =7.3)について, 地表で観察された折れ曲がりの地震断 層をもとに，2つの断層面から成る震源モデルを作り， 遠地実体波と比較してそれぞれの断層パラメ夕を得た。 そして断層の折れ曲がりの部分がバリアとなったことを 示した. 同様の断層の折れ曲がりによるバリアないしア スペリティ効果については, KING and NABELEK (1985) によってパターン化されている. また 1976 年 Tangshan 地震 $\left(M_{\mathrm{S}}=7.7\right)$ では，主断層である横ずれの断層運 動に誘発されて，その端付近に縦ずれ断層が形成された ことが波形のインバージョンから示唆された $[\mathrm{KIKUCHI}$ and KANAMORI (1986), NABELEK et al. (1987)].
一方, Ekstrom and Dziewonski (1985) や Kuge and KAWAKATSU (1990) は, 長周期波動のインバージョンで 得られるモーメントテンソル解 (CMT 解) の中にしば しば含まれる非ダブルカップル成分が, メカニズムの変 化するダブルカップル多重震源によって説明できること を指摘している.

\section{初期破壊の成長過程}

地震の初期の段階は, 小破壊から大きな破壊への成長 の物理的機構を知る上でとくに興味深い，大地震におい て一種のウオーミングアップ過程が存在することは, Fukao and Furumoto (1975) や Furumoto (1979) に よって示されている. MORI (1984) は 1965 年 Rat Is. 地 震 $\left(M_{\mathrm{W}}=8.7\right)$ について, 比較的初期の段階に小破壊のク ラスターが形成されていることを示した. また, UMEDA (1981) や梅田 (1985) は, 広帯域の近地地震記録をもと に, 初期破壊の過程で小さい領域から短周期地震波が集 中的に放出されることを発見し，この領域を震源核と呼 んだ.

\section{§6. 不規則震源過程の力学的裏づけ}

摩擦すべりの力学特性

波形のインバージョンにおいて我々が直接的に得る情 報はくいちがいの分布である．この情報を断層面上の強 
度分布に結びつけるには，すべりに関する何らかの力学 的モデルが必要となる.

たとえば，1970 年代の巨視的モデル（応力降下一定 のハスケルモデル）の段階では，古典的摩擦法則を基礎 とした割れ目モデルがよく用いられた。 古典的摩擦法則 では，すべりに対する抵抗力は「最大静止摩擦」と「す

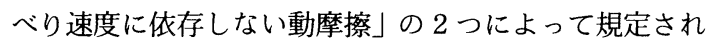
る.このモデルによれば, 応力降下は静止摩擦と動摩擦 の差にほぼ等しくなるので, 応力降下一定の経験則はご く素直に理解される．また，破壊伝播に対する媒質の強 度は表面エネルギーや応力拡大係数といった物理量で与 えられ，簡単なシミュレーションによって，割れ目が横 波の速さに近い速度で拡大することが確かめられる。一 方, 強度の不均一分布を導入することにより, 多重震源 のような破壊パターンを実現することもできる [Mikumo and Miyatake (1987)].

最近の摩擦すべり実験によると, 摩擦力は準静的な遅 いすべりに対して速度依存性を示し，すべり速度ととも に大きくなったり低下したりする [たとえば DIETERICH (1978)]. そして, この摩擦力の速度依存性は断層運動の 安定・不安定を左右する重要な要因となる [RUINA (1983), RICE and TsE (1986)]. 摩擦力のすべり速度依存 性は，実は，速いすべり速度でも見られる。たとえば OHNAKA et al. (1987) は伝播するすべり破壊の先端部で 応力やすべり量の時間変化を測定し, 摩擦応力がすべり 量やすべり速度に依存することを明らかにした。

\section{律速過程の存在}

摩擦力がすべり速度に依存する場合には，断層面の 「強さ」というあのをレオロジー風にとらえなければな らない，すなわち，せいぜい数秒間の時定数を持った衝 撃力に対する強さと, 数時間〜数年の時定数を持つ準静 的な力に対する強さとは区別されなければならない，そ の上で, 摩擦すべり特性の空間的不均一分布を考慮する 必要がある。

この観点に立つと，前震及び本震の破壊パターンを規 定する「アスペリティ」は「準静的な力に対して強いが 衝撃に対して弱い」部分であり, 一方, 余震の発生パ ターンを規定する「バリア」は「衝撃に対して強いが準 静的な力に対して弱い」部分と言えよう. 準静的にも衝 撃的にも強い領域は，もし存在するとすれば，地震発生 そのあのを抑えるであろうし, 逆に, 準静的にも衝撃的 にも弱い領域は破壊パターンには何の影響も与えないで あろうから，考慮すべき特性としては上述のアスペリ ティとバリアだけで十分であろう。

延性的バリアや断層面の折れ曲がりなどは破壊の伝播 を律速する原因となる。このような律速領域の存在は,
Discontinuity

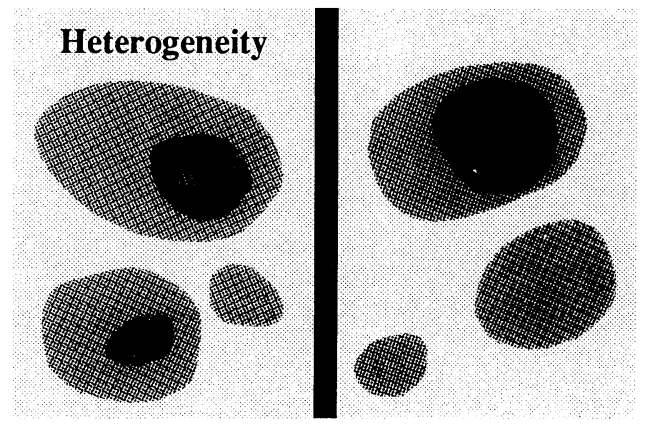

(a)

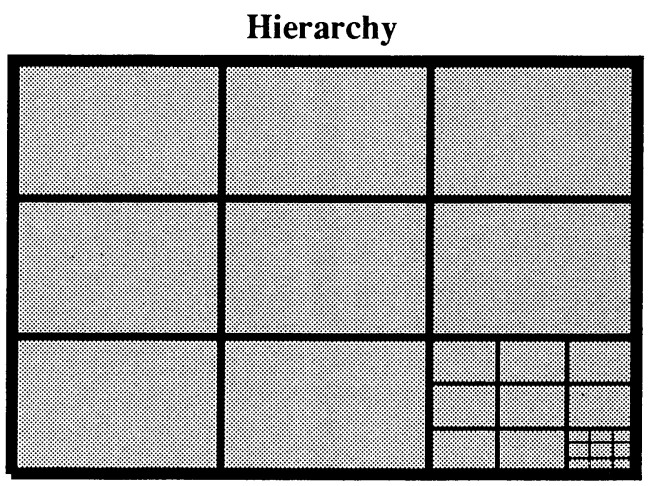

(b)

Fig. 6. Conceptional illustrations for basic properties of source complexity.

(a), (Upper) Discreteness of rupture propagation and heterogeneity of stress distribution; (b), (Lower) Hierarchy of rupture elements. The elements of upper three ranks are illustrated.

多重震源だけでなく，ほかの似たような連発型の現象に おいてあ重要である. そのような現象として，たとえば, 断層帯や沈み込み帯に沿った大地震の震源の移動 [MoGI (1968a), KELLEHER (1972)], 巨大地震において大きな余 震が主破壊の伝播をたどるように移動する現象 [MoGI (1968b)], あるいは内陸地震の余震域の移動 [SACKs et al. (1981)], さらには, Solomon 諸島でよく見られる, 数分から数日間隔の 2 4 連発型地震 [LAY and KANAMORI (1980), WESNOUSKY et al. (1986)] な゙がある.こ れらの現象の背景には, 爆発的な破壊伝播を阻止するよ うな何らかの律速過程が関与しているはずである.

\section{§ 7. まとめと今後の展望}

1980 年代の震源像は一言でいえば不規則震源過程で ある.しかしその内容はまだ混沌としている.多くの地 
震について多種多様な結果が得られてはいるが，そのう ちの何に注目すべきかについては研究者によって意見が 異なる．以下は筆者のかなり主観的なまとめと展望であ る.

不規則震源過程は次の 3 つの特性を持つ, すなわち

1) 破壊伝播の不連続性

2) 応力の不均一性

3) 破壊単位の階層性

である．概念図をFig. 6 に示す．まず，1) は狭義の意味 での多重震源性である. 放射される波動が離散的パルス であることに対応している，メカニズム変化にも密接に 関係している. 2) は断層面上のくいちがいの不均一分布 から類推される特性である. 波動上はパルスの大きさが ばらつくことに対応する．3) は波動の広帯域スペクトル （とくに短周期成分の励起）に対応している. 小破壊の連 鎖反応（クラスター形成）から大きな破壊へと転化する 力学過程に関係する. Fig. $6 \mathrm{~b}$ では 3 階層分だけ示して ある.

これらの特性はいずれも 70 年代前半の震源像（一定 応力降下のハスケルモデル）と相い対立する内容であ る.これに関し，一方は巨視的側面を他方はその微細構 造をモデル化したものといった妥協的見方もできよう.

しかし，より積極的には，微細構造についての知見を基 に巨視的モデルの力学的意味をあう一度吟味し直すべき であろう.

震源過程における微細構造と全体の関係は, それ自体 興味深い問題である. 一般に, 脆性材料の破壊では局所 的な不安定が全体の破壊へつながり易い，しかし，材料 が延性部分を含む場合にはいろいろな可能性がある. あ ちこちの局所的な破壊はそれだけで終わり，いくつか合 体して初めて全体の破壊が引き起こされるといった場合 も出てくる．このことはまた，巨視的モデルにおける 「応力降下一定」の経験則と局所的応力降下の不均一性 を関連づける上で重要となろう。

不規則震源過程の物理的性質を解明していくために は, 地震波解析, 室内実験及び計算機シミューレーショ ンを含む理論研究の共同作業が必要であろう。地震波解 析の立場からは，アスペリティ領域のすべり運動ととも に，それを取り巻く領域の長周期的なすべり特性を調べ ることが重要である。これに関連して，初期破壊から主 破壊に至る過程は大変興味深い。この過程は, おそらく は準静的過程であろう「破壊核の形成」とそのダイナ ミックな破壊への転化を含むであろう。また，小破壊か ら大破壊へ進む何らかの契機をも含むであろう. 希望と して, 小地震のままで終わる場合と大地震になる場合と の違いがこの初期破壊の過程に見い出されるであろう.
このような震源過程の微細構造を調べるにあたって は，観測する地震計の帯域とダイナミックレンジの広さ が決定的に重要である。これについて，近々整備される であろう広帯域デジタル地震観測網の記録に期するとこ ろが大きい.

\section{参考文献}

AkI, K., 1979, Characterization of barriers on an earthquake fault, J. Geophys. Res., 84, 6140-6148.

Archuleta, R. J., 1984, A faulting model for the 1979 Imperial Valley earthquake, J. Geophys. Res., 89, 4559-4585.

Burdick, L. J. and G. R. Mellman, 1976, Inversion of the body waves from the Borrego Mountain earthquake to the source mechanism, Bull. Seism. Soc. Am., 66, 1485-1499.

DAs, S. and K. Aкı, 1977, Fault planes with barriers: A versatile earthquake model, J. Geophys. Res., 82, 5658-5670.

DAs, S. and B. V. Kostrov, 1988, An investigation of the complexity of the earthquake source time function using dynamic faulting models, J. Geophys. Res., 93, 8035-8050.

Dieterich, J. H., 1978, Time-dependent friction and the mechanics of stick-slip, Pageoph, 116, 790-806.

Ekstrom, G. and A. M. Dziewonski, 1985, Centroidmoment tensor solution for 35 earthquakes in Western North America (1977-1983), Bull. Seism. Soc. Am., 75, 23-39.

FukAo, Y., 1970, Focal process of a deep focus earthquake as deduced from long-period $\mathrm{P}$ and $\mathrm{S}$ waves Bull. Earthquake Res. Inst., Tokyo Univ., 48, 707727.

Fukao, Y. and M. Furumoto, 1975, Foreshocks and multiple shocks of large earthquakes, Phys. Earth Planet. Interiors, 10, 355-368.

Fukao, Y. and M. Furumoto, 1985, Hierarchy in earthquake size distribution, Phys. Earth Planet. Interiors, 37, 149-168.

FukUyama, E. and K. IRIKURA, 1986, Rupture process of the 1983 Japan Sea (Akita-Oki) earthquake using a waveform inversion method, Bull. Seism. Soc. Am., 76, 1623-1640.

Furumoto, M., 1979, Initial phase analysis of $\mathrm{R}$ waves from great earthquakes, J. Geophys. Res., 84, 6867-6874.

Hartzell, S., 1989, Comparison of seismic waveform inversion results for the rupture history of a finite fault: Application to the 1986 North Palm Springs, California, Earthquake, J. Geophys. Res., 94, 75157534.

Hartzell, S. and D. V. Helmberger, 1982, Strong-motion modeling of the Imperial Valley earthquake of 1979, Bull. Seism. Soc. Am., 72, 571-596.

Haskell, N., 1969, Elastic displacements in the near- 
field of a propagating fault, Bull. Seism. Soc. Am., 59, 865-908.

平田隆幸, 1987, 新しい地震観とフラクタル, 地震 2 , 40, 459-467.

本多弘吉, 1954, 増訂地震波動, 岩波書店, pp. 154224.

IidA, M. and M. Hakuno, 1984, Study on complexity of large earthquakes, Proc. Japan Soc. Civil Eng., No. 350/I-2, 47-57.

ImAMURA, A., 1937, Theoretical and Applied Seismology, Maruzen, Tokyo, 358 pp.

Kanamori, H., 1977, The energy release in great earthquakes, J. Geophys. Res., 82, 2981-2987.

Kanamori, H. and D. L. Anderson, 1975, Theoretical basis of some empirical ralations in seismology, Bull. Seism. Soc. Am., 65, 1073-1095.

KANAMORI, H. and K. C. MCNALly, 1982, Variable rupture mode of the subduction zone along the Ecuador-Colombia coast, Bull. Seism. Soc. Am., 72, 1241-1253.

KanAmori, H. and G. S. Stew art, 1978, Seismological aspects of the Guatemala earthquake of February 4, 1976, J. Geophys. Res., 83, 3427-3434.

Kelleher, J. A., 1972, Rupture zones of large south American earthquakes and some predictions, J. Geophys. Res., 77, 2087-2103.

KIKUCHI, M. and Y. FukAo, 1985, Iterative deconvolution of complex body waves from great earthquakes- the Tokachi-Oki earthquake of 1968, Phys. Earth Planet. Interiors, 37, 235-248.

KikuCHI, M. and Y. Fukao, 1987, Inversion of longperiod $\mathrm{P}$ waves from great earthquakes along subduction zones, Tectonophysics, 144, 231-247.

KIKUCHI, M. and H. KANAMORI, 1982, Inversion of complex body waves, Bull. Seism. Soc. Am., 72, 491-506.

Kikuchi, M. and H. KANAmori, 1986, Inversion of complex body waves-II, Phys. Earth Planet. Interiors, 43, 205-222.

KING, G. and J. NABELEK, 1985, Role of fault bends in the initiation and termination of earthquake rupture, Science, 228, 984-987.

小山順二, 1983 , 伝播性破壊確率モデルと地震の震源ス ペクトル，地震 $2,36,225-235$.

小山順二, 1987,1983 年日本海中部地震の時間依存 モーメントテンソル, 地震 2, 40, 405-416.

Kuge, K. and H. Kaw AKATsu, 1990, Analysis of a deep 'non double couple' earthquake using very broadband data, Geophys. Res. Lett., 17, 227-230.

Langston, C. A. and D. V. Helmberger, 1975, A procedure for modeling shallow dislocation sources, Geophys. J. Roy. Astr. Soc., 42, 117-130.

LAy, T. and H. KANAMORI, 1980, Earthquake doublets in the Solomon Islands, Phys. Earth Planet. Interiors, 21, 283-304.

Lay, T. H., H. Kanamori and L. RufF, 1982. The asperity model and the nature of large subduction zone earthquakes, Earthquake Prediction Res., 1, 3-71.

Madariga, P., 1979, On the relation between seismic moment and stress drop in the presence of stress and strength heterogeneity, J. Geophys. Res., 84, 2243-2250.

松田時彦, 1988, 活断層の数的性質, “数理地震学 (III)”, 斎藤正徳編, 174-184.

Mikumo, T. and T. Miy atake, 1987, Numerical modeling of realistic fault rupture processes, "Seismic Strong Motion Synthetics", ed. by B. A. Bolt, Academic Press, 91-151.

Miyamura, S., S. Omote, R. Teisseyre and E. VesanEN, 1965, Multiple shocks and earthquake series pattern, Bull. Inter. Inst. Seism. Earthq. Eng. 2, 7192.

茂木清夫, 1967, 前震・群発地震について, 地震 2,20 特集, 143-146.

MogI, K., 1968a, Migration of seismic activity, Bull. Earthq. Res. Inst., 46, 53-74.

Mogi, K., 1968b, Development of aftershock areas of great earthquakes, Bull. Earthq. Res. Inst., 46, 175203.

MorI, J., 1984, Short- and long-period subevents to the February 4, 1965 Rat Islands earthquake, Bull. Seism. Soc. Am. 74, 1331-1347.

Mori, J. and K. ShimazaKi, 1984, High stress drops of short-period subevents from the 1968 Tokachi-Oki earthquake as observed on strong-motion records, Bull. Seism. Soc. Am., 74, 1629-1544.

Mori, J. and K. Shimazaki, 1985, Inversion of intermediate-period Rayleigh waves for source characteristics of the 1968 Tokachi-Oki earthquake, J. Geophys. Res., 90, 11374-11382.

NABELEK, J., 1984, Determination of earthquake source parameters from inversion of body waves, Ph. D. thesis, Mass. Inst. Technology, Cambridge, MA., $361 \mathrm{pp}$.

NABELEK, J., 1985, Geometry and mechanism of faulting of the $1980 \mathrm{El}$ Asnam, Algeria, earthquake from inversion of teleseismic body waves and comparison with field observations, J. Geophys. Res., 90, 12713-12728.

NABelek, J., Waing-Ping Chen and Hong Ye, 1987, The Tangshan earthquake sequence and its implications for the evolution of the North China basin, J. Geophys. Res., 92, 12615-12628.

Ohnaka, M., Y. Kuwahara and K. Yamamoto, 1987, Constitutive relations between dynamic physical parameters near a tip of the propagating slip zone during stick-slip shear failure, Tectonophysics, 144, 109-125.

Oıke, K., 1969, The deep earthquake of June 22, 1966 in Banda Sea: A multiple shock, Bull. Disas. Prev. Res. Inst., Kyoto Univ., 19, 55-65.

Olson, A. H. and R. J. Aspel, 1982, Finite faults and inverse theory with applications to the 1979 Impe- 
rial Valley earthquake, Bull. Seism. Soc. Am., 72, 1969-2001.

Papageorgiou, A. S. and K. Aki, 1983, A specific barrier model for the quantitative description of inhomogeneous faulting and the prediction of strong ground motion. Part I. Description of the model Bull. Seism. Soc. Am., 73, 693-722.

RICE, J. R. and S. T. TSE, 1986, Dynamic motion of a single degree of freedom system following a rate and state dependent friction law, J. Geophys. Res., 91, 521-530.

Rudnicki, J. and H. Kanamori, 1981, Effects of fault interaction on moment, stress drop and strain energy release, J. Geophys. Res., 86, 1785-1793.

RUfF, L. and H. KanAmori, 1983, The rupture process and asperity distribution of three great earthquakes from long-period diffracted P-waves, Phys. Earth Planet. Interiors, 31, 202-230.

Ruina, A., 1983, Slip instability and state variable friction laws, J. Geophys. Res., 88, 10359-10370.

RundLe, J. B. and H. Kanamori, 1987, Application of an inhomogeneous stress (patch) model to complex subduction zone earthquakes: a discrete interaction matrix approach, J. Geophys. Res., 92, 26062616.

Sacks, I. S., A. T. Linde, J. A. Snoke and S. Suehiro, 1981, A slow earthquake sequence following the Izu-Ohshima earthquake of 1978, in "Earthquake Prediction" ed. by D. W. Simpson and P. G. Richard, An International Review Maurice Ewing Series 4, AGU, Washington D.C., 617-628.

SATAKE, K., 1989, Inversion of tsunami waveforms for the estimation of heterogeneous fault motion of large submarine earthquakes: the 1968 TokachiOki and 1983 Japan sea earthquakes, J. Geophys. Res., 94, 5627-5636.

SAto, T., 1985, Rupture characteristics of the 1983 Nihonkai-Chubu (Japan Sea) earthquake as inferred from strong motion accelerograms, J. Phys. Earth, 33, 525-557.

TAKENAKA, H., 1987, Strong-motion modeling of the Izu-Hanto-Toho-Oki earthquake by inversion method, J. Fac. Sci. Hokkaido Univ., Ser. VII (Geophysics), 8, 155-172.

TакEO, M., 1987, An Inversion method to analyze the rupture processes of earthquakes using near-field seismograms, Bull. Seism. Soc. Am., 77, 490-513.

TAKEO, M., 1988, Rupture process of the 1980 IzuHanto-Toho-Oki earthquake deduced from strong motion seismograms, Bull. Seism. Soc. Am., 78, 1074-1091.

UMEDA, Y., 1981, An earthquake source model with a ripple generating core, J. Phys. Earth, 29, 341-370.

梅田康弘, 1985, 断層運動の加速之震源核の形成, 地震 $2,38,203-215$.

Wesnoousky, S. G., L. Astiz and H. Kanamori, 1986, Earthquake multiplets in the southeastern Solomon Islands, Phys. Earth Planet. Interiors, 44, 304318.

Yoshida, S., 1986, A method of waveform inversion for earthquake rupture process, J. Phys. Earth, 34, 235-255.

Yoshida, S., 1988, Waveform inversion for rupture processes of two deep earthquakes in the Izu-Bonin region, Phys. Earth Planet. Interiors, 52, 85-101. 